\title{
FLIGHT-ASSOCIATED DISGHARGE PATTERN IN A WEAKLY ELEGTRIC FISH, GNATHONEMUS PETERSII (MORMYRIDAE, TELEOSTEI)
}

by

\section{BERND KRAMER ${ }^{1}{ }^{2}$ )}

(Laboratoire de Physiologic Nerveuse, Département de Neurophysiologie Sensorielle, C.N.R.S. Gif-sur-Yvette, France, and Universität Konstanz, Fachbereich Biologie, Konstanz, German Federal Republic)

(With I Figure)

(Acc. 30-VIII-1975)

\section{INTRODUCTION}

In certain weakly electric fishes of the families gymnotids and mormyrids the involvement of the electric organ discharge in social signalling has been established. According to the type of discharging their electric organ, weakly electric fish may be divided into two groups: those which discharge brief pulses, separated by long and variable intervals ("pulse species", all mormyrids, some gymnotids) and those which produce long pulses, separated by short and highly stable intervals ("tone species", many gymnotids, Gymnarchus).

Behavioural analyses of electric communication have dealt only with a few species. Among "pulse species", a transient discharge rate acceleration was found to be associated with overt attack in Gymnotus carapo (BLACKCleworth, I970; Valone, 1970; Westby, 1974), in Gnathonemus petersii (Bauer, 1972; Bauer \& Kramer, i973; Moller \& Bauer, 1973; Kramer, i974; Bell et al., 1974; Kramer \& Bauer, 1976), and in Mormyrus rume (KRAMER, I976). A complex discharge pattern of a very high rate occurs associated with lateral display in $G$. petersii. In between attacks and lateral displays, this species exhibits a detailed electrical interaction with the pulses of a partner (BAUER \& Kramer, I974; Kramer, I974; Russell et al., 1974).

I) This study was sponsored by fellowships and by a research grant Nos. $\mathrm{Kr} 446 / \mathrm{I}$, $\mathrm{Kr} 446 / 2$ and $\mathrm{Kr} 446 / \mathrm{Ib}$ by the Deutsche Forschungsgemeinschaft (DFG). The author is especially indebted to $\mathrm{Dr} \mathrm{Th}$. SzABo for his invitation to work in his laboratory, and for stimulating discussions. Likewise, I wish to thank Prof. Dr H. MARKL for critical conments on the paper.

2) Present address: Universität Konstanz, Fachbereich Biologie, D-775 Konstanz, Postfach 7733, German Federal Republic. 
Among "tone species", brief discharge frequency rises and interruptions were reported in Sternopygus macrurus during courtship behaviour (HopKINS, 1972, 1975) and in Eigenmannia virescens during agonistic behaviour (Hopkins, 1974).

Until now, no specific signal has been established which is associated with fleeing from an attacking partner, except if one considers the complete discharge arrest in retreating $G$. carapo (BLACK-CLEworth, 1970) as a signal. It is the purpose of the present paper to describe the discharge pattern of fleeing $G$. petersii, when they are attacked by a residential partner.

\section{MATERIALS AND METHODS}

The general conditions of housing and feeding the fish, as well as the experimental set-up and recording methods are described elsewhere (KRAMER, I974).

There does not exist a method to reliably separate the pulses of two freely swimming fish of the same species. For that reason, a closely related species, $M$. rume, was used to attack $G$. petersii. Since pulse length is different in both species, separation was possible by means of an electronic circuit.

In a parallel series of experiments, the attacking fish was a $G$. petersii whose electric organ had been silenced eight weeks before the experiment, by a section of the spinal cord just cranially to the electric organ, situated in the caudal peduncle. The tail fin is not immobilised by this operation due to the presence of specialised tendons (ci., for example Bruns, I971) connecting the tail fin with muscle portions situated cranially to the caudal peduncle.

The experiments were made with seven $G$. petersii (I $2-17.5 \mathrm{~cm}$ ) of unknown age and sex which were attacked by the $M$. rumc $(20.5 \mathrm{~cm})$ or by the "silenced" $G$. petersii $(\mathrm{I} 5.5 \mathrm{~cm})$.

The behaviour of the fishes, as well as the digital display of a quartz clock, were filmed and taped by a video equipment. Simultaneously, the electrical activity and the time marks, generated by the clock in intervals of a second, were recorded on magnetic tape for off-line computer analysis (Didac, Intertechnique). Synchronisation of audio and video recordings was achieved by means of the time marks.

Prior to the experiments, the $M$. rume or the operated $G$. petersii had been habituated to the experimental tank, which was provided with a hiding tube of plastic mesh, for at least three days. An experiment consisted of putting one of the seven $G$. petersii into the tank of the $M$. mime or of the operated $G$. petersii, for three minutes a day.

\section{RESULTS}

The residential fish, resting in its hiding tube, usually did not move when the other fish was introduced into its tank. The latter swam around continuously, exploring its new environment and probing the corners of the tank with its chin appendage. After some while (approx. Io to up to 30 s) the territory owner attacked the intruder, especially when it came near its hiding tube, or when it tried to swim into it. The first attack was often preceded by several to and fro movements of the fish within the tube. In most instances, the attacked fish tried to avoid being bitten by a quick escape reaction. It is the discharge pattern displayed during this behaviour which is shown in 
Figs. Ic and d. During the course of the experiment, a long series of many attacks and escape reactions followed. The overall activity of the introduced animal (referred to as "fleeing fish" in the following paragraphs) is shown in Fig. Ib.
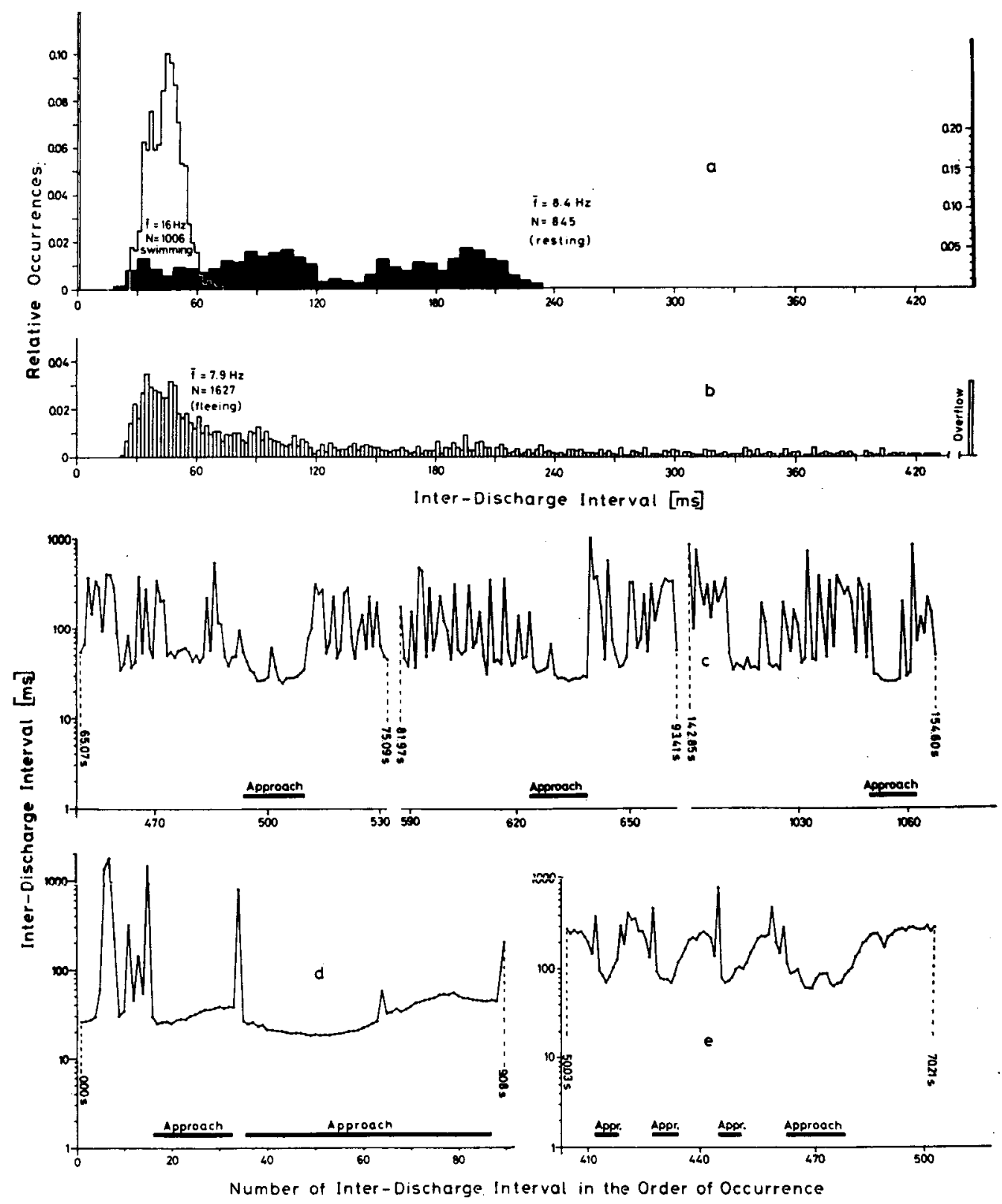
A comparison of this histogram with the histograms of an isolated animal (Fig. Ia) reveals several important differences: i) The mean discharge rate of a fleeing fish (7.9 Hz; Fig. Ib) is approximately half that of an isolated, swimming fish ( $16 \mathrm{~Hz} ;$ Fig. Ia, white histogram), although the fleeing animal swims continuously, too. The discharge rate of the fleeing fish is essentially the same as the rate displayed by an isolated, resting specimen (8.4. $\mathrm{Hz}$; Fig. Ia, black histogram). ii) I.ike the swimming histogram, the fleeing histogram is unimodal, but the mole exhibits a higher rate. The mode is identical to the "burst activity mole" (BAUER, 1974) of the resting histogram (Fig. Ia, black). iii) The fleeing histogram displays by far the longest intervals, exceeding one second, although the mode is of a high discharge rate. By its extremely great range of intervals the histogram resembles most the histogram of an attacking $G$. petersii (KRAMER \& BAUER, I976, Fig. 3). In every other aspect, such as mean discharge rate (3I vs $7.9 \mathrm{~Hz}$ ), number (two $v s$ one) and position of modes the differcnces between the two histograms are very distinct, however $(p<0.0$, Kolmogorov-Smirnov test).

Fig. Ic shows the actual discharge activity of a $(i$. petersii put into the tank of a $M$. rume. (i. petersii increases and regularises its discharge rate, displaying intervals of about $25-30 \mathrm{~ms}$, during the attack of the opponent (indicated by horizontal, black bars) and its own escape reaction. In many cases, there is no gradual decline of interval length (i.c. smooth discharge rate increase) from the low rate-interburst activity, as it is secn during attack (BAIER, 1972; BEI, ct al., 1974; KRAMER, 1974). On the contrary, $G$. petersii steps down to a short interval length rather sudclenly. This is

Fig. Ia: Interpulse interval histogram of a resting (black) and a swimming, isolated Gnathonemus petersii (white). White ordinate indicates relative occurrences in white histogram, black ordinatc in black histogram. $\bar{f}=$ mean discharge ratc. Redrawn from Kramer, I974. b: interpulse interval histogram of a $G$. petersii being attacked by a resident $M$. rume. Note the high varialiility of interval lengths in b ats compared to a and the coincidence of the mode with the first mode (burst activity mode) in Fig. Ia, black. The three histograms are normalised to cover the same area, i.e. equal areas are the same densities of probability. $c$ : Sequential representation of the discharge activity of a $G$. petersii in the presence of an aggressive $M$. rume. The instances when the $M$. rume attacked are indicated by horizontal black bars (approach). Each point is one interval, plotted sequentially on the abscissa. The ordinate is the length of each interval (logarithmic scale). Note that during approach by the $M$. rume interval length decreases rapidly (i.e. discharge rate rises), and that there is a tendency to regularise interval length. Periods without attacks are left out, as indicated. $d$ : as $c$, but the attacking animal is a $G$. petersii without electric organ discharge. Note the step-like discharge rate increase and long regularisation. c: as $\mathrm{d}$, but the approaching "silent" $G$. petersii vecred away as soon as the attacked animal, which did not move, increased its discharge rate. 
demonstrated clearly in the second and third approach in Fig. Ic and in Fig. Id. A simultaneous superposition of aggressive and fleeing tendencies may have producerl the rather complex pattern in Fig. Ic at the left (first approach). It displays the smooth interval length decline of an aggressive signal, but it differs from it in that a transient stationary interval length is attained already well over $20 \mathrm{~ms}$.

Does a step-like discharge rate increase occur only when there is an attack-elicited escape-reaction? Fig. Ie is a record from a completely immobile $G$. petersii which increased its discharge rate substantially each time when the territory owner, a $r$. petersii without discharge (spinal section), approached. It clearly shows that a step-like discharge rate increase may be performed in an agonistic situation without being associated with a change in motor activity. The fact that the attacking animal (which was the smaller one) veered away within some centimeters of distance without butting, may explain why the discharge rate did not rise as high as in Fig. Ic and d. It would be interesting to know whether it was these signals which made the attacking fish turn away.

\section{DISCUSSION}

The biological significance of the "fleeing signals" is difficult to assess. One obvious advantage of a regularisation at a high rate would be a stable response of the mormyromast electroreceptors (Kraner-FEIL, I976) and more input to the electrosensory system (Lissmann \& Machin, 1958; Machin \& Lissmann, i960; Szabo \& Fessard, i974; Scheich \& BulLOCK, 1974) per unit time and hence better temporal resolution of the electrical field distortions caused by the presence of the attacking fish. Against the electrolocation function of the "fleeing signals" argues the fact that G. petersii escapes by quick lateral tail fin movements which by itself greatly distort the electric field. Another conceivable function of the fleeing discharge pattern might be an appeasement behaviour. This seems to be very unlikely, since by discharging $G$. petersii attracts attention by the opponent (KRAMER \& Bauler, I976, and Kraner, subm.). G. petersii which have been bitten and heavily persecuted for some while stop to discharge altogether (personal observation). Apparently, the best thing a G. petersii can do to avoid being attacked by a conspecific is to stop to discharge completely. A more likely hypothesis might be a function as a threatening behaviour, especially when the result presented in Fig. Ie is considered. However, the possibility has also to be kept in mind that the "fleeing signal" just represents an incidental response to changed motor activity or to a vegetative reaction. The first of these two possibilities does not seem very likely when (a) the 
differences between the swimming and fleeing histograms (Fig. I), and (b) the result presented in Fig. Ie are considered.

In conclusion, it was found out that $G$. petersii displays a specific discharge pattern when it flees from an attacking opponent. The histogram displayed by inferior animals is dissimilar to the three types of discharge activities which are known in $G$. petersii.

\section{SUMMARY}

A Gnathonemus petersii which is put into the tank of a Mormyrus rume, or of an electrically silenced $G$. petersii, displays a discharge rate which is only one fourth $(8 \mathrm{~Hz})$ the rate exhibited by an attacking, territory-defending animal. In both instances, the variability of intervals is great. In contrast to the bimodal histogram of an attacking animal, the histogram of an inferior, fleeing fish displays only one mode. This mode is identical to the burst activity-mode of the resting histogram, and different from the swimming histogram mode. So the histogram displayed by an attacked and persecuted animal is significantly different from the histograms exhibited by i) isolated resting, ii) isolated swimming, and iii) attacking fish.

During an attack-elicited escape reaction, $G$. petcrsii increases its discharge rate up to $55 \mathrm{~Hz}$ in a step-like fashion, while regularising the length of successive intervals ("fleeing signal"). The step-like discliarge rate increase is also shown by the receiver of an Approach who does not move. This suggests that the step-like discharge rate increase, associated with the escape reaction, is not an incidental response to changed motor activity. The "fleeing signal" presumably is i) an incidental response to a vegetative reaction, or ii) it may have the significance of a signal communicating a socially relevant message (e.g. threat).

\section{REFERENCES}

BAUER, R. (1972). High electrical discharge frequency during aggressive behaviour in a mormyrid fish, Gnathoncmus petersii. - Experientia 28, p. 669.

- (1974). Electric organ discharge activity of resting and stimulated Gnathonemus petersii (Mormyridae). -- Behaviour 50, p. 306-323.

— \& KRAMER, B. (I97.3). Relations entre le comportement agressif du mormyridé Gnathonemus petersii et sa décharge électrique. - I. Physiol. (Paris) 67, p. 240$24 \mathrm{I}$ A.

-_ \& - ( 1974$)$. Agonistic behaviour in mormyrid fish: latency-relationship between the electric discharges of Cinathonemus petersii and Mormyrus rume. Experientia 30, D. $5 \mathrm{I}^{-52}$.

Bell, C. C., Myers, J. P. \& Russeicl, C. J. (1974). Electric organ discharge patterns during dominance related behavioral displays in Gnathonemus petersii (Mormyridae). -- J. comp. Physiol. 92, p. $201-228$.

Black-Cleworth, P. (I970). The role of electrical discharges in the non-reproductive social behaviour of Gymnotus carapo (Gymnotidae, Pisces), - Anim. Behav. Monogr. 3, p. I-77.

Bruns, V. (I97I). Elektrisches Organ von Gnathoncmus (Mormyridae). Elektrische Platte und Innervation. - Z. Zellforsch. 122, p. 538-563.

Hopkins, C. D. (I972). Sex differences in electric signalling in an electric fish. Science 176 , p. I035-1037.

- (1974). Electric communication: function in the social behavior of Eigenmannia virescens. - Behaviour 50, p. 270-305.

-_ (I975). Electric communication in the reproductive behavior of Sternopygus macrurus. -- Z. Tierpsychol. 35, p. 518-535. 
Kramer, B. (1974). Electric organ discharge interaction during interspecific agonistic behaviour in freely swimming mormyrid fish. A method to evaluate two (or more) simultaneous time series of events with a digital analyser. - I. comp. Physiol. 93, p. 203-235.

(1976). Electric signalling during aggressive behaviour in Mormynus rume (Mormyridae, Teleostei). - Naturwiss. 63, p. 48.

- \& BAUER, R. (1976). Agonistic behaviour and electric signalling in a mormyrid fish, Gnathonemus petersii. - Behav. Ecol. Sociobiol. 1, p. 45-6r.

Lissmann, H. W. \& Machin, K. E. (I958). The mechanism of object location in Gymnarchus niloticus and similar fish. - J. Exptl. Biol. 35, p. 45I-486.

Machin, K. E. \& Lissmann, H. W. (I960). The mode of operation of the electric receptors in Gymnarchus niloticus. - J. Exptl. Biol. 37, p. 80I-8II.

Mollek, P. \& Bautr, R. (I973). 'Communication' in weakly electric fish, Gnathonemus petersii (Mormyridae). II. Interaction. - Anim. Behav. 21, p. 50I-512.

Russell, C. J., Myers, J. P. \& Bell, C. C. (1974). The echo response in Gnathonemus petersii (Mormyridae). - J. comp. Physiol. 92, p. I8I-200.

Scherch, H. \& Bullock, T. H. (1974). The detection of electric fields from electric organs. - In: Handbook of sensory physiology vol. III/3 (Ed. by A. Fessard), p. 20I-256. Springer Verlag, Berlin, Heidelberg, New York.

Szabo, T. \& Fessard, A. (1974). Physiology of electroreceptors. - In: Handbook of sensory physiology, vol. III/3 (Ed. by A. FessArD), p. 59-I24. Springer Verlag, Berlin, Heidelberg, New York.

Valone, Jr., J. A. (1970). Electrical emissions in Gymmotus carapo and their relation to social behavior. - Behaviour 37, p. I-I4.

Westby, G. W. M. (1974). Assessment of the signal value of certain discharge patterns in the electric fish, Gymnotus carapo, by means of playback. - J. comp. Physiol. 92, p. 327-341.

- (I974). Comparative studies of the aggressive behaviour of two gymnotid fish. Anim. Behav. 23, p. Iog-I3o.

\section{ZUSAMMENFASSUNG}

Der schwachelektrische Fisch Gnathonemus petersii sendet in einem fremden Revier mit einer um etwa das Vierfache niedrigeren durchschnittlichen Entladungsrate (ca. $8 \mathrm{~Hz}$ ) als ein aggressives, revierverteidigendes Tier. Wie bei diesem ist die Variationsbreite der Intervalle groß. Im Unterschied zu dem Histogramm eines angreifenden Tieres, das zwei Modi besitzt, hat das Histogramm eines inferioren, fluchtbereiten Fisches nur einen einzigen Modus. Dieser Modus ist mit dem "Burst-Aktivitäts"-Modus des Ruhehistogramms identisch, nicht jedoch mit dem Modus des Schwimmhistogrammes. Das Histogramm eines Tieres im fremden Revier, in dem es angegriffen und in die Flucht gejagt wird, unterscheidet sich signifikant von den drei bisher bekannten Histogrammtypen, die man bei (1) isolierten ruhenden, (2) isolierten schwimmenden oder bei (3) einen Partner angreifenden Fischen findet.

Während des Angegriffenwerdens und der Fluchtreaktion erhöht G. petersii sprungartig seine Entladungsrate auf bis zu $55 \mathrm{~Hz}$; gleichzeitig wird die Länge aufeinanderfolgender Intervalle "regularisiert". Die sprunghafte Erhöhung der Entladungsrate wird auch dann gezeigt, wenn das Tier auf eine StoBintention des Revierinhabers hin sich nicht vom Platz rührt. Dies legt die Vermutung nahe, daß die sprunghafte Erhöhung der Entladungsrate während der Fluchtreaktion nicht eine Begleiterscheinung der erhöhten motorischen Aktivität sein kann, sondern entweder a) eine Folgeerscheinung einer vegetativen Reaktion ist oder b) spezifischen Signal-(z.B. Droh-) Charakter hat. 
Note added in proof:

Two references mentioned in the text can now be cited more precisely:

Kramer, B. (submitted). The attack frequency of Gnathonemus petersii towards electrically silent (denervated) and intact conspecifics, and towards another mormyrid (G. niger).

KraMer-FFI., U. (1976). Analyse der sinnesphysiologischen Figenschaften der Einheit Elektrorezeptor (Mormyromast) - sensible Faser des schwachelektrischen Fisches (Gnathonemus petersii (Mormyridae, Teleostei). Dissertation, J.-W.-Goethe-University, Frankfurt/Main.

To the list of species, displaying a transient discharge rate acceleration during overt attack, given in the introduction, the mormyrid Grathonemus niger may be added (KRAMER, submitted). 